\title{
Discussão Virtual sobre "Interação em Epistemologia Genética"
}

\section{Organização e Comentários: \\ Fernando Becker ${ }^{1}$ \\ Rafael dos Reis Ferreira ${ }^{2}$}

\begin{abstract}
As relações entre o sujeito e o seu meio consistem numa interação radical, de modo tal que a consciência não começa pelo conhecimento dos objetos nem pelo da atividade do sujeito, mas por um estado indiferenciado; e é deste estado que derivam dois movimentos complementares, um de incorporação das coisas ao sujeito, o outro de acomodação às próprias coisas (PIAGET, Nascimento da inteligência na criança, [1936] 1978, p. 386).
\end{abstract}

\section{Resumo}

O objetivo deste texto é apresentar as ideias e as reflexões que surgiram do Debate sobre o conceito de interação em Epistemologia Genética na Lista de Discussão do GPEGBrasil, entre os meses de Outubro e Dezembro de 2012. A lista congrega, hoje, quase 300 pesquisadores em Epistemologia e Psicologia Genéticas de todo o Brasil. A intenção dos organizadores é registrar, na memória escrita, em forma de uma publicação acadêmica, as contribuições deste Debate para o esclarecimento deste conceito. Para preservar a espontaneidade do Debate, optamos por conservar as ideias exatamente como elas apareceram na Lista GPEGBrasil.

\section{Discussion about " Interaction in Genetic Epistemology"}

\begin{abstract}
The objective of this paper is to present the ideas and reflections that arised from the debate on the concept of interaction in the Discussion's List in Genetic Epistemology of the GPEGBrasil, between the months of October and December 2012. The list brings together today, nearly 300 researchers in Psychology and Genetic Epistemology of throughout Brazil. The intention of the organizers is to record in the memory written, in the form of a academic publishing, the contributions of this debate to clarify this concept. To preserve the spontaneity of debate, we decided to keep the ideas exactly as they appeared in the List GPEGBrasil.

\footnotetext{
1 É doutor em Psicologia Escolar e do Desenvolvimento Humano pela Universidade de São Paulo e professor titular da Universidade Federal do Rio Grande do Sul. Autor de: Epistemologia do professor e Epistemologia do professor de matemática, ambos da Ed. Vozes.

2 Rafael dos Reis Ferreira é licenciado, bacharel e mestre em Filosofia pela Universidade Estadual Paulista (UNESP-Marília). Atualmente faz seu doutorado em Filosofia na Universidade Estadual de Campinas (Unicamp).
} 


\section{Considerações Iniciais}

Gostaríamos de destacar neste texto um belo exemplo de uso de recursos da Internet para o debate de ideias entre pessoas envolvidas em torno de questões e temas comuns. Trata-se de um debate em um espaço virtual entre pessoas distantes em um espaço real que interagiram virtualmente entre si para tentarem dissolver questões que causam, de algum modo, espanto ou admiração ${ }^{3}$.

Quando se fala em debate, a palavra construtivismo merece, neste caso, destaque: aprendemos com a Epistemologia Genética que o conhecimento está em constante construção e que todos podem ser operários na construção do edifício do conhecimento que não cessa de crescer tanto sob a perspectiva da expansão de uma teoria em questão quanto sob a perspectiva do sujeito que procura compreender tal teoria. Sempre na dependência, é claro, da qualidade da ação do sujeito.

Nesse sentido, segundo a perspectiva construtivista, não existe (ou não deve existir) o grande intelectual, o sábio, o coordenador ou o mediador do debate, o detentor e o transmissor do conhecimento, mas todos podem contribuir e fazer parte dessa construção que se assemelha a um movimento dialético.

Sem incorrer em exageros, o GPEGBrasil, em seus debates já ocorridos $^{4}$, parece transparecer este tipo de movimento dialético, característico

\footnotetext{
3 Para Platão e Aristóteles a Filosofia começa no tò $\theta a u \mu a ́$ Ł̌ıv (tò thaumazein) que significa espanto, admiração, maravilhamento, espetáculo, etc.

4 Aqui mencionamos o debate que ocorreu em Fevereiro de 2012 na Lista do GPEGBrasil sobre o caso da "Criança Prodígio". O debate foi publicado na Revista Schème, e está disponível no seguinte endereço: http://www2.marilia.unesp.br/revistas/index.php/scheme/article/view/2571; que corresponde ao vol. $4 \mathrm{n}^{\circ} 2$.
} 


\section{Sthòme \\ Revista Eletrônica de Psicologia e Epistemologia Genéticas}

da filosofia nascente, afigurando-se como um belo exemplo de construção de conhecimento.

Gostaríamos, aqui, de apresentar, então, um destes belos exemplos de debate que ocorreu no GPEGBrasil entre os meses de Outubro e Dezembro de 2012. Debate intitulado pelo professor Fernando Becker de “Interação em Epistemologia Genética: uma discussão na Lista GPEGBrasil” na qual se procurou discutir questões em torno do conceito de interação na teoria de Piaget.

Nós gostaríamos de apresentar o Debate na forma como ele ocorreu, a forma de diálogo. A nossa tarefa aqui é de organizadores, mas talvez um pouco mais que isso, pois organizamos as contribuições e ensaiamos as "Convergências" e "Divergências" que identificamos no Debate. Inicialmente o professor Fernando Becker faz uma contextualização do Debate e apresenta o tema a ser debatido. Em seguida apresentamos o Debate propriamente dito.

Após a apresentação do Debate, ousamos, em uma seção intitulada "Convergências", traçar algumas linhas de consenso gerais que identificamos nas contribuições dos debatedores. Apresentamos, depois, na seção “Divergências”, as principais divergências surgidas no embate das ideias. Em seguida, apresentamos as principais questões remanescentes do Debate e, também, ousamos tecer comentários gerais em uma última seção intitulada "Comentários dos organizadores". Finalizaremos, então, com breves "Considerações Finais".

Optamos por conservar as contribuições como elas apareceram na Lista GPEGBrasil. Conservamos, pois, as manifestações na sua espontaneidade. Não as devolvemos aos debatedores para correções, acréscimos, melhorias. Entendemos que isto constituiria outro trabalho que, eventualmente, alguém possa fazer. 


\section{Sthìme \\ Revista Eletrônica de Psicologia e Epistemologia Genéticas}

\section{Contextualização do Debate}

Fernando Becker: No último Proepre, em Setembro, em Águas de Lindóia, ouvi algumas reclamações sobre o uso da Lista Gpegbrasil@... - está servindo apenas para recados pessoais, para divulgar sites, etc. e não para discutir assuntos de Epistemologia Genética. Comentando esse fato com Silvia Parrat-Dayan e Juan Delval, prometi a eles por no ar assuntos temáticos e polêmicos de Epistemologia Genética. Comecei, em 15 de outubro, com o conceito de "interação". A repercussão foi além do que eu presumia, incluindo algumas de muito boa qualidade. Coletei todas elas neste arquivo, incluindo as destes dois últimos dias (Ricardo Tassinari e Lino de Macedo). Para minha surpresa, nem Silvia Parrat-Dayan nem Juan Delval responderam à provocação - nunca é tarde demais... Espero ter lembrado de todas as contribuições. Abraços a todos e bom proveito. Fernando Becker.

\section{Apresentação do Debate}

\section{Em 15 de outubro de 2012, Fernando Becker pôs na Lista de Discussão do} GPEGBrasil o tema da Interação:

Caros participantes da Lista Gpegbrasil@... Entendo que esta Lista deve orientar-se prioritariamente para discussões a respeito de temas de Epistemologia Genética (EG). No início, Ricardo Tassinari levantou um problema de interpretação. Infelizmente, a discussão não evoluiu e não foram propostos novos temas. Pois eu estou propondo um que me incomoda faz tempo. Como penso que se trata de uma interpretação que atinge o coração da EG, gostaria de ouvi-los a respeito, já agradecendo as contribuições. Abraços, Fernando Becker.

Parece-me que o termo interação, da Epistemologia Genética, é utilizado de forma incorreta, na maior parte das vezes, inclusive por piagetianos e, inclusive, por mim, em textos mais antigos. Exemplos tirados de dissertações ou teses: "O aluno já conhece as novas situações com as quais irá interagir"; "O sujeito... em constante interação com a realidade..."; “... do sujeito em interação com o objeto..."; "Para compreender e aplicar todas as funcionalidades do ambiente [informático] é necessário interagir com o mesmo..."; "Se a criança interage com a música..."; "a criança deve relacionar as propriedades dos elementos com os quais estiver interagindo..."; “... as crianças que interagem com os sons”. 
O verbo interagir refere-se sempre aos dois polos da relação: sujeito e objeto interagem, indivíduo e meio interagem, alunos e professor interagem - o verbo quer dizer que não só o sujeito age sobre o objeto, mas que o objeto também "age" sobre o sujeito (por intermédio da assimilação) e dessas ações mútuas surge um tertium que não é nem o sujeito nem o objeto, nem a soma dos dois, mas uma nova síntese.

As formas corretas seriam: "Cada vez que sujeito e objeto interagem..."; “... a prática pedagógica em Química se faz pelas interações... entre docentes e estudantes..."; "Sujeito e música interagem..."; "Aluno e professor OU aluno e classe interagem...". O professor age, não interage!

As dificuldades de conceituar acomodação incidem, com certeza, sobre a compreensão da interação. $\mathrm{O}$ meio age sobre o indivíduo somente se o indivíduo o assimilar; o indivíduo poderá, com essa assimilação, se desestabilizar (desequilíbrio); ele age, então, sobre si, modificando-se ou modificando seus esquemas assimiladores (acomodação), para melhor assimilar da próxima vez.

Então, o verbo interagir comporta sempre, de acordo com o conceito de interação da Epistemologia Genética, dois polos: sujeito e objeto, indivíduo e meio social, aluno e professor, homem e universo, organismo e meio ambiente, criança e computador, etc. Toda vez que o conjugamos para um dos polos apenas, estamos minimizando seu significado. Assim, é errado dizer que o indivíduo interage com o meio, o professor interage com o aluno, o sujeito interage com o objeto, o homem interage com o universo. É correto dizer que professor, indivíduo, sujeito age, respectivamente, sobre o aluno, o meio, o objeto.

O indivíduo só pode agir, não interagir; o meio só pode agir, não interagir; o sujeito só pode agir, não interagir. Resta compreender como o objeto ou o meio, físico ou social, age sobre o organismo, o indivíduo ou o sujeito.

Em Paulo Freire, encontramos um verbo com o mesmo estatuto do verbo interagir da Epistemologia Genética. Trata-se do verbo dialogar. Um exemplo: uma Orientadora Pedagógica chamou os professores da escola para uma reunião. E foi avisando: "Eu os chamei para esta reunião porque a Diretora quer dialogar pra vocês". Se eu falo e o interlocutor não responde, não aconteceu o diálogo. Do mesmo modo, se eu dou uma aula maravilhosa e os alunos não respondem, não houve interação. Será ridículo dizer que "Eu interagi com os alunos", como frequentemente se ouve. Ironizando: O professor interagiu, mas os alunos continuaram entediados, desligados...

Não será por tal precária ou equivocada compreensão que o construtivismo escolar deu no que deu? 
Acompanhemos o debate ocorrido na Lista GPEGBrasil.

\section{Em 15 de Outubro de 2012, Antonio Carlos J. Zanni de Arruda escreveu:}

Prezado Prof. Fernando Becker. Concordo contigo em gênero, número e grau. Aproveitando o termo que você utilizou "coração", digo que na interação piagetiana está a dialética de sua epistemologia. Um abraço. Antonio Carlos.

\section{Em 15 de Outubro de 2012, Nelson Pedro escreveu:}

Prof. Fernando Becker,

Concordo com a maioria das considerações que o Senhor fez sobre o conceito de interação.

Eu, inclusive, já tinha perguntado para o Ricardo a respeito de textos do Piaget sobre esse assunto.

Algo, para mim, é certo:

1. a interação, a meu ver, é semelhante ao conceito de dialética (apontada por Antonio Carlos);

2. realmente, o sujeito só pode agir. Agora, ele só age porque de alguma maneira certos estímulos (meio) foram significativos para ele. Nesse sentido, poderíamos considerar que o meio age sobre o sujeito e, este, por sua vez busca agir sobre o meio, como forma de equilibrar-se. Um dos problemas que vejo é como compatibilizar o fazer ciência com a noção que sujeito e objeto são inseparáveis. Parece-me que só o campo da fenomenologia, com a valorização do preconceito, é capaz.

Enfim, não sei se me fiz evidente. Todavia, concordo com Antonio Carlos que o conceito de interação, ao lado do de construção, são centrais na obra piagetiana.

Quanto à escola, acredito que o problema não está no entendimento do conceito. Penso que o problema, infelizmente, é de analfabetismo funcional.

Abraços,

Nelson Pedro

Em 15 de Outubro de 2012, Thiago Iwaszko Marques Proença escreveu:

Boa noite a todos os colegas!

Acredito que, para usarmos os termos piagetianos, precisamos ter muita clareza quanto aos seus significados. Realmente, o conceito de interação surge como 
parte de uma teoria que defende o processo cognitivo como sendo uma construção, onde, pela minha compreensão até o momento, ao sujeito precisa ser oferecida oportunidades para que possa elaborar seu conhecimento. Uma boa chance para que isso aconteça são as ocasiões em que ele pode ter assimilações e acomodações, a partir de relações (interações) que ele estabelece com o meio.

Minha dúvida é a seguinte: as práticas escolares, em sua grande maioria, estão baseadas em fundamentos construtivistas? Há erros de interpretações, é verdade, porém percebo que, mais do que uma má definição do que realmente seja construtivista (como no caso da confusão conceitual entre interação e agir sobre) está uma ausência de práticas que se baseiem nessa teoria. Hoje mesmo ouvi de uma colega que "existem alunos cujo conhecimento parece ser inato". É preciso haver definições terminológicas quando estudamos Piaget e sua teoria, porém, talvez, seja preciso descer um degrau e mostrar a grande parte dos docentes as possibilidades que se abrem com a adoção de uma concepção construtivista. Mais do que erros embasadas por interpretações erradas, podemos presenciar deturpações geradas a partir de empirismos ou de apriorismos, enraizadas na tradição escolar.

Thiago Iwaszko Marques Proença

\section{Em 15 de Outubro de 2012, Susana Frisancho escreveu:}

Querido Fernando, Que maravilloso es el portugués!!! He aprendido mucho con tu último correo, no solo de precisiones importantes y piagetanas del verbo interacción (con el dialogar de Freire) sino también del idioma portugués (que no sabes cuanto me gustaría aprender!). Gracias por el envio. Lo voy a compartir con los chicos que aquí te quieren y aprecian mucho.

Un fuerte abrazo con mucho cariño! Susana

Em 16 de Outubro de 2012, Tristan Torriani escreveu:

Prezad@s Coleg@s,

Com relação às considerações do Prof. Becker, gostaria de indicar o livro do meu ex-orientador Arno Ros, Prof. titular aposentado da Otto-vonGuerickeUniversität Magdeburg, titulado Matéria e Espírito.

http://www.amazon.de/Materie-Geist-Eine-philosophischeUntersuchung/dp/3897853973/ref=sr_1_1?ie=UTF8\&qid=1350395741\&sr=8-1

O Prof. Ros redigiu também uma extensa monografia sobre Piaget. 
http://www.worldcat.org/title/genetische-epistemologie-jean-piagetsresultate-und-offene-probleme/oclc/464601567

Tomando por base a filosofia tardia de Wittgenstein, que procura esclarecer conceitos por meio da clarificação das regras (gramaticais) de seu uso, Ros substitui a concepção quase-Saussureana de Piaget e consegue elaborar um modo metódico de introduzir conceitos (entendidos agora como capacidades classificatórias). Deste modo, Ros elabora uma epistemologia genética normativa (que os wittgensteinianos denominariam 'gramatical').

Em seu livro "Materie und Geist", o Prof. Ros procura, através de uma construção gradual e normativa-gramatical, mostrar como se pode transicionar entre, por ex., o conceito de simples movimento (que não é necessariamente intencional), e o de um ato intencional. Basicamente, precisamos ver quais são as condições necessárias e suficientes para nós, enquanto observadores externos, atribuirmos a capacidade de agir voluntariamente ou não a algo que inicialmente se constitui para nós como objeto indefinido.

Outra referência que me parece muito importante é o trabalho do Prof. Hans Joas sobre G. H. Mead, pois este último deu muita importância à questão da interação, distinguindo, por ex. entre um mero brincar (play) e o jogar (game), em que se seguem regras.

http://www.amazon.com/G-H-Mead-Contemporary-Reexamination/dp/0262600293/ref=sr_1_1?s=books\&ie=UTF8\&qid $=1350396500$ \&sr=1-1\&keywords=joas + mead

Atenciosamente, Tristan

\section{Em 16 de Outubro de 2012, Clélia Ignatus escreveu:}

Olá a todos

Sempre entendi que no processo de construção do conhecimento não é possível estabelecer o que se refere ao sujeito e o que se refere ao objeto. Já li em algumas obras que na teoria piagetiana a construção do conhecimento se dá pela interação sujeito-objeto, mas que acontece no interior do sujeito e ficava sempre refletindo no significado disto. Quando Fernando estabelece a distinção entre interação e ação me veio aquela sensação de "por que não pensei nisto antes".

Clélia

Em 16 de Outubro de 2012, Eliane Paganini da Silva escreveu:

Olá a todos. 
Minhas considerações não são especificamente sobre o termo interação em EG, mas sim com relação à afirmação final do prof. Becker sobre o construtivismo escolar e respectivamente as considerações do Prof. Nelson Pedro. Concordo com a preocupação do prof. Becker ressaltando que algumas pesquisas e demais publicações realizadas na Unesp de Araraquara sob coordenação da Profa. Cilene Chakur e seus orientandos nos mostram que "as idéias e considerações de Piaget parecem ter chegado à escola de forma descontextualizada e destituídas dos seus significados originais, segundo atestam algumas pesquisas" (CHAKUR, 2009, p. 15 - O construtivismo na Pesquisa, vol. 1.- Cap. 1. O construtivismos entre professores do ensino fundamental: um exemplo de assimilação deformante). Sendo este um aspecto a ser considerado, acredito que mais que um problema de "analfabetismo funcional" (de uma quantidade muito grande de professores e de regiões tão distintas - apesar de sabermos que essas dificuldades existem) como afirma o Prof. Nelson, a dificuldade em compreender alguns conceitos piagetianos possam ser, sim, por conta do que chega e de como chega até os professores tais conceitos (que são disseminados por nós pesquisadores e de acordo com nosso entendimento dos conceitos).

As pesquisas às quais a autora se refere são:

MASSABINI, V. G. O construtivismo do professor: de Piaget às ideias e práticas de professores de Ciências. Araraquara: Unesp, 2005. Tese (Doutorado em Educação Escolar).

QUIM, O. Teoria e prática na percepção de professoras: concepções construtivistas que fundamentam o processo de alfabetização em escolas de Alto Araguaia - MT. Araraquara: Unesp, 2004. Dissertação (Mestrado em Educação Escolar).

SILVA, R.C. Saberes construtivistas de professores do Ensino Fundamental: alguns equívocos e seus caminhos. Araraquara: Unesp, 2005. Tese (doutorado em Educação Escolar).

TORRES, L. de C. Do discurso pedagógico ao discurso dos professores: resistência ao Construtivismo e profissionalização docente. Araraquara: Unesp, 2004. Dissertação (Mestrado em Educação Escolar).

Espero contribuir para a reflexão nesse sentido...

Eliane Paganini da Silva

Em 16 de Outubro de 2012, Maria Lucia Moro escreveu:

Olá Fernando, 
Muito bom você ter chamado a atenção para o conceito de interação e as confusões que há tempos aparecem a respeito dele. Confusões que, concordo, perturbam, atrapalham, em vários aspectos, trabalhos inspirados na epistemologia genética em várias áreas, sobretudo na de educação.

Eu concordo com a maior parte de suas interpretações. Porém, tenho algumas restrições e/ou observações a fazer sobre algumas delas, afora pensar que vale a pena complementar alguns pontos. Bom, é o seguinte:

- não concordo quando você, parece, aproxima o conceito de interação com a ideia de diálogo (P. Freire). E com o exemplo que você dá sobre dar uma aula maravilhosa, os alunos não responderem e então, não haver interação. (Ou será que entendi errado o sentido deste exemplo? Corrija-me se assim for). Ocorre que INTERAÇÃO, segundo a epistemologia genética, SEMPRE HÁ; sempre a ação de um indivíduo afeta o meio-ambiente e vice-versa, sempre, e ao mesmo tempo. E sempre essa troca tende com maior ou menor probabilidade ao equilíbrio, para cumprir as funções invariantes do desenvolvimento. Por isso, e concordo, dá arrepios quando se emprega o sentido atual, corriqueiro, leigo - e na moda - de interação em estudos inspirados na teoria (interagir virou "conversar", por exemplo). É importante lembrar a todos, INTERAÇÃO é um tipo de relação científica, explicativa entre fenômenos, de inspiração dialética. É um modelo de relação entre outros. Adotado Piaget, é o modelo de relação que rege sempre as relações entre o indivíduo e o meio ambiente (no plano psicológico), entre o organismo e o meio em que ele vive/sobrevive (no plano biológico) e, então, entre o sujeito e o objeto (no plano epistemológico). E isto adquire pleno sentido quando se sabe de Piaget ter adotado a ideia de que a vida, um organismo vivo, é um sistema aberto. Aliás, o modelo de interação para ocorrer construção, só ganha sentido quando se retoma esta ideia fundante de que a vida é um sistema aberto.

No meu entender, ainda vale o conselho de ler, reler e reler "Biologia e Conhecimento", onde tudo isto é destrinchado. É leitura difícil, concordo, mas se tem que estudar isto ali. Mas há outros textos que ajudam também; por exemplo: as entrevistas de Bringuier em "Conversando com Piaget" (principalmente a décima, sobre a fenocópia - o que nos faz sempre lembrar de algo útil: que Piaget foi, antes de mais nada, um biólogo); ainda há um texto, velho conhecido, de César Coll e Christiane Gilliéron no livro “Piaget e a Escola de Genebra", organizado pela Luci B. Leite. É texto que ajuda iniciantes e que sempre me valeu, ao menos com estudantes de pós-graduação.

Bom, seria isto. E valeu sua decisão de lidar com temas como esses. Tomara que se pudesse mesmo ter um fórum, assim, para se estudar Piaget.

Abração, Maria Lucia Moro 


\section{Em 16 de Outubro de 2012, Nelson Pedro escreveu:}

Caros Colegas, primeiramente, gostaria de parabenizar o Prof. Fernando e demais colegas por esse excelente debate. Desde ontem, me pego pensando no assunto da interação e suas consequências nas escolas.

Eu já emiti uma parte do que penso. Com certeza, não me fiz claro.

Tenho a dizer que a discussão levantada pelo Mestre Becker só reafirma o que Piaget disse a respeito do desenvolvimento: ELE ESTÁ NO AGIR. Partindo desse pressuposto, tenho a impressão que o conceito de interação, salvo melhor juízo, tem a função de salientar que essa ação não é executada no vazio. Agora, como disse com muita propriedade, é a ação o "coração" da teoria piagetiana.

Sobre os docentes, recordo-me de uma fala de Yves [de la Taille], quando era seu aluno. Ela me foi muito esclarecedora, pois não conseguia entender a dificuldade dos meus alunos em compreender Piaget. Além de não ser uma obra que se entrega facilmente, ele disse algo assim, comparando ao computador: é como se tentássemos instalar uma linguagem (soft) em uma máquina não compatível (hard). Pois bem, aliado ao analfabetismo funcional (continuo a defender tal tese), penso que os professores e nós mesmos, piagetianos (não todos, é evidente), não estamos conseguindo construir uma máquina que nos faça compreender o interacionismo de Piaget.

Abraços a todos, Nelson Pedro

\section{Em 17 de Outubro de 2012, Adrián O. D. Montoya escreveu:}

Parabéns Fernando pela iniciativa.

Acho que a lista, como você diz, deve servir para orientar as discussões. Vejo que as discussões estão bem interessantes e com boa participação. Concordo com todos que a "interação" é central na obra de Piaget.

Como alguns expressaram, penso também que o conceito de interação envolve a indissociabilidade entre organismo e meio e entre sujeito o objeto, porém, penso também que essa indissociabilidade somente adquire significação se considerarmos tanto a dimensão do "funcionamento" como as "estruturações" sucessivas da adaptação.

Na obra "O nascimento da inteligência na criança", Piaget, na parte introdutória, conceitua o processo adaptativo da criança pequena em termos de interação entre os esquemas de ação (esquemas hereditários ou adquiridos) e o meio. Essa adaptação, como sabemos, prolonga, como restruturações, a própria vida orgânica. 
Agora, a adaptação no plano dos primeiros esquemas de ação são completamente diferentes do processo de adaptação no plano do conceito e da própria prática científica.

Assim, numa conferência, do ponto de vista do entendimento dos interlocutores, poderá ou não existir interação.

Se existir entendimento recíproco, haverá interação no plano do conceito; contudo, se não houver tal tipo de interação poderá existir nesse mesmo momento, interações práticas e mesmo bioquímicas. Por exemplo, a relação que eu, como pai, mantinha com o meu nenê não é interação? Essa relação não poderá ser conceitual, mas não poderá ser prática ou sensório-motora. Outro exemplo: frequentemente chamo o meu cão boxer de "cagão" e ele move seu rabinho em sinal de afeição; já uma criança, mesmo pré-operatória, não vai gostar de ser chamada desse modo.

Então, do meu ponto de vista, para Piaget, a natureza da indissociabilidade entre sujeito e objeto, entre organismo e meio, se torna mais clara dependendo do nível de análise em que nos encontramos.

Estou no Peru e amanhã estarei debatendo com uma Vygotskiana de México, na PUC de Lima. Possivelmente esta questão apareça com maior vigor. Agradeço pela oportunidade de pensar esse ponto. Um abraço, Adrián.

\section{2 de Outubro de 2012, Ângela Inauário escreveu:}

Essas interações que não ocorrem no plano conceitual podem levar ao desenvolvimento?

Abraços a todos, Ângela

\section{Em 03 de Novembro de 2012, Ricardo Tassinari escreveu:}

Prezados Fernando, Antônio Carlos, Nelson, Tristan, Eliane, Clélia, Maria Lúcia, Adrián e demais membros.

Gostaria de entrar na discussão sobre a noção de interação em Psicologia e Epistemologia Genéticas. Só agora tive tempo de escrever alguma coisa.

O e-mail inicial do Fernando em relação à noção de interação me sugere a seguinte questão: será que o sujeito e o meio tem o mesmo peso na interação?

Outra questão correlacionada com essa é sobre a noção de "ação", como também consta no e-mail do Fernando e em alguns e-mails na continuação da discussão. 
Na concepção piagetiana, a ação não é mero movimento; toda ação requer um objetivo (but). Segundo a definição de ação no livro Les liaisons analytiques et synthétiques dans les comportements du sujet, temos que "Def.1: É ação toda conduta (observável exteriormente e por interrogatório clínico) visando um objetivo (but) do ponto de vista do sujeito considerado." Assim, é esquisito falar em "ação" do meio; o meio não age como o sujeito age, pois o meio não tem um objetivo (but) como o sujeito tem.

Ou ainda, segundo a teoria, o sujeito é um organismo, tem uma organização e, para Piaget, o objetivo é fruto dessa organização; já o meio não tem a organização que o indivíduo tem, por isso não tem objetivo.

Nesse sentido, me parece que sujeito e meio não tem o mesmo peso na interação. A interação é mais deslocada para o lado do sujeito, por assim dizer.

Se a interação é, como disse Fernando, "uma nova síntese" e não apenas só sujeito ou só objeto, essa nova síntese é realizada pela estrutura do sujeitoorganismo (lembro aqui de meu ex-orientando Vicente Marçal que insistia em usar na Dissertação dele o termo composto sujeito-organismo, para salientar e dar ênfase a esse importante aspecto do sujeito na teoria piagetiana, termo que às vezes adoto quando se trata de lembrar esse aspecto).

Nesse sentido a interação é diferente da interação em química, em que os pesos para os polos da interação são, em geral, iguais.

Mais ainda, no Nascimento da Inteligência da Criança, quando Piaget discute a "Teoria das tentativas", nas Conclusões, em relação à teoria da "tentativa e erro", mostra que as tentativas do sujeito são guiadas por seu sistema de significações, e, nesse sentido, são tentativas guiadas, no qual o papel do acaso é minimizado. Pode-se dizer que as tentativas são orientadas também pelo objeto, mas nesse caso, é, principalmente, pelo objeto construído pelo sujeito mais do que pelo próprio objeto mesmo que se imporia (numa espécie de empirismo). Se, como disse o Nelson, "ele só age porque de alguma maneira certos estímulos (meio) foram significativos para ele", por outro lado, é a estrutura do sujeito que determina o que é significativo para ele.

Ou seja, se o sujeito não é senhor da situação, pois é o objeto que tem que se mostrar, na ação de um sujeito que o busca conhecer. Por outro lado, o sujeito é "o centro" da interação; daí ele ser egocêntrico no início e ir se descentrando com a interação (sem nunca se descentrar completamente, ao meu ver, pois o objeto sempre será um limite jamais atingido e sempre o objeto para ele dependerá das suas estruturas).

Concordo com a Maria Lúcia que "interação sempre há" e que "é um tipo de relação científica, explicativa entre fenômenos" e que se deve considerar seus 
vários lados, em especial, o biológico, o psicológico e o epistemológico, e concordo também com o Adrián sobre a questão da interação ser diferente nos diversos níveis de estruturação do sujeito.

Nesse sentido, gostaria de finalizar minhas considerações colocando uma questão que me parece bem difícil em relação à noção de interação (aproveitando que o Fernando tem estudado as epistemologias dos professores de matemática), mas que é central em Teoria do Conhecimento: interação e objetos matemáticos.

Ela é uma questão central, pois todos os nossos conhecimentos científicos são permeados pelos objetos matemáticos.

A questão é: Interagimos com o objeto matemático?

Para ser mais específico, consideramos o conjunto dos números naturais $\mathrm{N}=\{0$, $1,2,3 \ldots\}$. Interagimos com o conjunto dos números naturais? (Lembrando que também nesse caso o sujeito não é senhor da situação, pois, o objeto matemático guarda uma objetividade frente à subjetividade do sujeito, ou seja, não há o meu conjunto dos números naturais, o seu conjunto, etc., mas um conjunto que é objeto de conhecimento para os diversos sujeitos matemáticos).

Abraços, Ricardo Tassinari.

Em 04 de Novembro de 2012, Lino de Macedo comenta o texto de Ricardo Tassinari:

Ricardo: Prezados Fernando, Antônio Carlos, Nelson, Tristan, Eliane, Clélia, Maria Lúcia, Adrián e demais membros.

Gostaria de entrar na discussão sobre a noção de interação em Psicologia e Epistemologia Genéticas. Só agora tive tempo de escrever alguma coisa.

O e-mail inicial do Fernando em relação à noção de interação me sugere a seguinte questão: será que o sujeito e o meio tem o mesmo peso na interação?

Lino: Penso que sim, desde que troquemos sujeito por "organismo" e pensemos interação como necessidade de o organismo complementar, via interação, algo que lhe falta e sempre faltará para sustentar sua vida. É o caso, por exemplo, das necessidades de oxigênio, vitaminas e tantos outros ingredientes que o organismo, por um processo digestório, assimila recorrendo a elementos do meio ambiente. $\mathrm{O}$ mesmo se aplicaria ao problema do conhecimento. $\mathrm{O}$ organismo nasce podendo "afirmar" certos reflexos e tendências elementares do ponto de vista afetivo, mas não sabe "negar", daí um estado inicial de indiferenciação sujeito-objeto, que exigirá no mínimo sete longos primeiros anos de vida. Daí também a exigência de Piaget de que a interação caracterize- 


\section{Şchème \\ Revista Eletrônica de Psicologia e Epistemologia Genéticas}

se por uma relação de interdependência, em que os termos que a realizam sejam irredutíveis, complementares e indissociáveis. Superar a indiferenciação é, neste sentido, conquistar a interdependência, via construções genéticas e estruturalistas ao mesmo tempo.

Ricardo: Outra questão correlacionada com essa é sobre a noção de "ação", como também consta no e-mail do Fernando e em alguns e-mails na continuação da discussão.

Lino: O problema da ação é que ela não é falsa nem verdadeira em si mesma, como quer Piaget. Sua "verdade" ou "falsidade" só se expressa como interação sujeito-objeto. No começo, como informações a posteriori, por exemplo, não alcançar um objetivo, ter dor, etc. ou por antecipações, pré-correções ou inferências, como acontecerá com a construção dos esquemas operatórios.

Ricardo: Na concepção piagetiana, a ação não é mero movimento; toda ação requer um objetivo (but). Segundo a definição de ação no livro Les liaisons analytiques et synthétiques dans les comportements du sujet, temos que "Def.1: É ação toda conduta (observável exteriormente e por interrogatório clinico) visando um objetivo (but) do ponto de vista do sujeito considerado." Assim, é esquisito falar em "ação" do meio; o meio não age como o sujeito age, pois o meio não tem um objetivo (but) como o sujeito tem.

Lino: É certo que o meio não tenha um objetivo como a ação, mas o objeto, com quem o sujeito interage, faz parte do meio (interno ou externo ao próprio sujeito). E o objeto, por definição etimológica, limita as ações do sujeito, oferece resistências, reage, expressa observáveis relacionados a suas coordenações. É certo também que o objeto pode não ter objetivos, como os do sujeito, mas por ser o alvo da ação deste pede uma consideração recíproca. Neste sentido etimológico, pode-se pensar até ao contrário. Sujeito é o que está submetido ao objeto. Daí a importância que Piaget atribui ao sujeito ativo.

Ricardo: Ou ainda, segundo a teoria, o sujeito é um organismo, tem uma organização e, para Piaget, o objetivo é fruto dessa organização; já o meio não tem a organização que o indivíduo tem, por isso não tem objetivo.

Nesse sentido, me parece que sujeito e meio não tem o mesmo peso na interação. A interação é mais deslocada para o lado do sujeito, por assim dizer.

Se a interação é, como disse Fernando, "uma nova sintese" e não apenas só sujeito ou só objeto, essa nova síntese é realizada pela estrutura do sujeito-organismo (lembro aqui de meu exorientando Vicente Marçal que insistia em usar na Dissertação dele o termo composto sujeitoorganismo, para salientar e dar ênfase a esse importante aspecto do sujeito na teoria piagetiana, termo que às vezes adoto quando se trata de lembrar esse aspecto).

Nesse sentido a interação é diferente da interação em química, em que os pesos para os pólos da interação são, em geral, iguais.

Mais ainda, no Nascimento da Inteligência da Criança, quando Piaget discute a "Teoria das tentativas" nas Conclusões, em relação à teoria da "tentativa e erro", mostra que as tentativas 


\section{Sichème \\ Revista Eletrônica de Psicologia e Epistemologia Genéticas}

do sujeito são guiadas por seu sistema de significações, e, nesse sentido, são tentativas guiadas, no qual o papel do acaso é minimizado. Pode-se dizer que as tentativas são orientadas também pelo objeto, mas nesse caso, é, principalmente, pelo objeto construído pelo sujeito mais do que pelo próprio objeto mesmo que se imporia (numa espécie de empirismo). Se, como disse o Nelson, "ele só age porque de alguma maneira certos estímulos (meio) foram significativos para ele", por outro lado, é a estrutura do sujeito que determina o que é significativo para ele.

Lino: Penso que nessa questão devemos sempre considerar a tríade - sujeito, objeto e interações - como interdependentes. As interações sujeito-objeto, por exemplo, nos modelos de Piaget (Equilibração das estruturas cognitivas) são representadas por setas, ou seja, expressam funções entre um e outro. Nestas funções nunca se observa a primazia de um lado (o sujeito, por exemplo) sobre outro (o objeto). A única exceção, creio, é no modelo IA, quando sujeito e objeto aparecem indiferenciados, em suas interações com os reflexos.

Ricardo: Ou seja, se o sujeito não é senhor da situação, pois é o objeto que tem que se mostrar na ação de um sujeito que o busca conhecer, por outro lado, o sujeito é "o centro" da interação; dai ele ser egocêntrico no início e ir se descentrando com a interação (sem nunca se descentrar completamente, ao meu ver, pois o objeto sempre será um limite jamais atingido e sempre o objeto para ele dependerá das suas estruturas).

Concordo com a Maria Lúcia que "interação sempre há" e que "é um tipo de relação científica, explicativa entre fenômenos" e que se deve considerar seus vários lados, em especial, o biológico, o psicológico e o epistemológico, e concordo também com o Adrián sobre a questão da interação ser diferente nos diversos níveis de estruturação do sujeito.

Nesse sentido, gostaria de finalizar minhas considerações colocando uma questão que me parece bem difícil em relação à noção de interação (aproveitando que o Fernando tem estudado as epistemologias dos professores de matemática), mas que é central em Teoria do Conhecimento: interação e objeto matemáticos.

Ela é uma questão central, pois todos os nossos conhecimentos científicos são permeados pelos objetos matemáticos.

A questão é: Interagimos com o objeto matemático?

Para ser mais específico, consideramos o conjunto dos números naturais $N=\{0,1,2,3 \ldots\}$. Interagimos com o conjunto dos números naturais? (Lembrando que também nesse caso o sujeito não é senhor da situação, pois, o objeto matemático guarda uma objetividade frente a subjetividade do sujeito, ou seja, não há o meu conjunto dos números naturais, o seu conjunto, etc. mas um conjunto que é objeto de conhecimento para os diversos sujeito matemáticos.)

Lino: $\mathrm{O}$ conceito de números naturais me parece um ponto de chegada, ou seja, uma abstração refletida que demanda pensamento formal. As crianças descobrem, inventam ou constroem, por exemplo, noções de equivalência, de correspondência, de unidade em seu sentido operatório concreto. Outra coisa, penso ser interessante separarmos a matemática do matemático. O matemático, a criança no caso, faz abstrações pseudo-empíricas e lógico-matemáticas sobre 
números, mas os números, eles mesmos, pertencem à matemática e enquanto sistema de objetos reagem a qualquer mal-entendido do sujeito, porque não são uma extensão dele. Neste sentido, penso que a Matemática é como a Linguística. Uma coisa é aquele que fala, escreve, lê, ou seja, o sujeito ou o comportamento leitor, outra coisa é a língua, a semântica, etc.

\section{Em 04 de Novembro de 2012, Fernando Becker escreveu:}

Participantes da Lista Gpegbrasil@...

Agrupei, segundo a ordem de chegada, num arquivo eletrônico (ver anexo), as contribuições para a discussão sobre o conceito de Interação, em Epistemologia Genética. Abraços a todos e obrigado àqueles que fizeram repercutir esta discussão. Fernando Becker

Entretanto, novas contribuições continuaram a aparecer na Lista Gpegbrasil@. Acompanhemo-las.

\section{Em 07 de Novembro de 2012, Ricardo Pereira Tassinari escreveu:}

Obrigado Fernando, Lino e a todos que participaram da discussão!

Gostaria de deixar registrado que a pergunta: se interagimos com os objetos matemáticos, foi-me feita pelo meu orientando Alexandre Ferraz, depois da palestra do Fernando, no II Colóquio Internacional de Epistemologia e Psicologia Genéticas. Abraços, Ricardo

Em 07 de Novembro de 2012, Fernando Becker escreveu: Caros Ricardo Tassinari e Alexandre Ferraz

Bela e provocadora pergunta [Interagimos com o objeto matemático?]! Tentarei uma resposta.

Como assimilamos objetos matemáticos e temos que produzir numerosas e sucessivas modificações em nossos esquemas assimiladores, para dar conta das múltiplas dificuldades que esses objetos põem à nossa compreensão, configurase interação entre nós e esses objetos. Nós agimos sobre objetos matemáticos e, kantianamente, eles se escondem, resistem a serem compreendidos, "agem" pondo obstáculos à nossa compreensão. Se não agirmos sobre eles, assimilandoos e, frente às dificuldades de assimilação, modificando nossos esquemas assimiladores, não os compreenderemos. Temos que transformá-los para compreendê-los; ao transformá-los, nos transformamos. Essa dupla transformação produz um tertium - testemunha do processo de interação. Pensa-se que o conceito piagetiano de interação refere-se apenas às relações dos seres sociais (indivíduos ou instituições) entre si. Esse conceito, Piaget o estende 
a toda a realidade, inclusive à realidade física. Se eu quero compreender a matéria e saber se o Bóson de Higgs existe, terei que construir uma máquina gigantesca, tubular, de forma circular, colocar ímãs gigantes ao longo dessa tubulação, para acelerar partículas a velocidades próximas às da luz e observar, com aparelhagem sofisticada, as colisões dessas partículas, etc. etc. Numa palavra, terei que agir sobre a matéria num nível infinitesimal para "obrigá-la" a dizer o que ela é. Se ela responder - dizem os cientistas do LHC, instalado em território francês e suíço, que isso aconteceu - então poderemos afirmar: Houve interação! Resultado: apareceu um tertium, uma novidade cognitiva, que é a testemunha dessa interação: $\mathrm{O}$ bóson de Higgs foi empiricamente detectado! Nem a matéria, nem os físicos do LHC serão doravante os mesmos. Se não aparecer esse tertium, não se pode afirmar a existência de interação.

(Se eu cometi algum non sense em termos de conhecimento físico, o que é altamente provável, não se preocupem que meus orientandos Júnior Frezza e Luciano Luduvico, professores de Física, em breve irão me corrigir...).

Entendo, pois, que há interação sempre que agirmos sobre um outro (alium) e obtivermos resposta desse outro, mesmo que esse outro seja uma pedra. Se eu agir sobre a pedra submetendo-a a alta temperatura a ponto de derretê-la, ao decantar esse líquido, a pedra me dirá de que ela se compõe. Essa "resposta" da pedra me dirá que houve interação entre eu e ela.

Nós não podemos interagir com os objetos matemáticos; nós apenas podemos agir sobre eles. Se houver interação será entre nós e eles. Interação é um substantivo que designa duas ações, ao mesmo tempo opostas e complementares, que produzem um tertium; ações do sujeito $\boldsymbol{e}$ do objeto. Esse tertium manifesta-se ao mesmo tempo como transformação estrutural do sujeito e modificação do objeto.

Ricardo e Alexandre, abraços e obrigado pela pergunta. Abraços a todos. Fernando Becker

\section{Em 07 de Novembro de 2012, Gabriel Carvalho Junior escreveu:}

Mestre Fernando, esta é a minha primeira participação na lista. Entrei recentemente no grupo e acho que tenho muito mais a aprender do que a contribuir. Mas, essa discussão sobre interação me chamou muito a atenção e gostaria de expor uma dúvida que me acompanha há algum tempo.

Muito interessante essa colocação sobre a interação. Entendo que quando você faz a metáfora do experimento como uma tentativa de "fazer a natureza revelar seus segredos", trata-se, no fundo, de interpretações que os cientistas fazem a partir de uma série de elementos que são assimilados. Então, construímos os aceleradores de partículas para verificar se o modelo concebido é coerente com 
os dados experimentais. Esse movimento de construir teorias a partir de dados experimentais, teorias essas que geram novas predições, predições que podem (ou não) ser verificadas por dados experimentais, dados que dão abertura para novas teorias... é o próprio movimento do fazer científico e que possui um paralelo interessante com a história do desenvolvimento individual.

Como você disse, quando derretemos a pedra e avaliamos o que acontece, nem nós nem a pedra seremos mais os mesmos.

Nesse sentido, o bóson de Higgs não seria um "objeto matemático" com o qual os cientistas tentam interagir por meio do experimento no LHC? Essa é uma grande dúvida que sempre me pego pensando e que o seu texto me ajudou a organizar melhor. Se partirmos do pressuposto que nunca conseguiremos ver um bóson, tampouco perceber qualquer interação com ele (diferentemente do que ocorre com uma pedra, por exemplo), essa partícula acaba sendo o resultado de um conjunto de modelos matemáticos que guardam alguma lógica interna. Nesse sentido, o bóson não passaria de um objeto matemático. $\mathrm{O}$ experimento realizado não "prova" a existência, apenas fornece um conjunto de medições que guardam coerência com o modelo conhecido. É possível, inclusive, que determinados pontos do modelo teórico sejam revistos a partir das interpretações das medições.

Não seria, então, correto dizer que o experimento media a interação entre o sujeito (o pesquisador) e o objeto matemático (o modelo-bóson de Higgs)?

Gostaria de terminar agradecendo o privilégio que é poder participar dessa lista de discussão. Um abraço a todos. Gabriel Carvalho

\section{Em 08 de Novembro de 2012, Patrícia Celis Murillio escreveu:}

Olá Gabriel,

Também enveredo por estes pensamentos. Esta é uma reflexão embasada na teoria crítica?

Se for, o interessante é que parece que você começou a encontrar respostas que busco, há um tempo, referentes às questões metodológicas quantitativas.

A teoria crítica ajuda a pontuar como o contexto da pesquisa pode deixar de ser revelado na interação do sujeito com o meio - sem a leitura dos determinantes sociais.

Pode ser que tenha me equivocado, mas há uma questão referente à interpretação metodológica. 
Tudo o que enxergamos hoje pode não passa de uma grave miopia. Att Patrícia

\section{Em 08 de Novembro de 2012, Gabriel Carvalho Junior escreveu:}

Olá Patrícia.

Obrigado pela contribuição. Não conheço a fundo a Teoria Crítica, mas posso dizer que, sim, há um pouco dela (até o limite em que consigo ir nesse campo) nessas reflexões. $\mathrm{O}$ interessante é que os dados de pesquisa não são obtidos, porque eles não têm significado em si. Eles são construídos em um processo de significação do qual fazem parte o pesquisador, os sujeitos pesquisados e o contexto. Talvez por isso muitos espíritos positivistas não aceitem os trabalhos qualitativos como "fazer ciência". O engraçado é que, mesmo os trabalhos quantitativos mais "duros" são, em essência, construções.

Por exemplo, qual é a evidência inequívoca e definitiva de que a Teoria da Evolução de Darwin é uma verdade? Ok, há registros fósseis, análises genéticas, ... que são coerentes com a teoria. Mas, quem nos permite dizer que isso mostra, definitivamente, a Verdade (com V maiúsculo)?

Os dados são construídos. Mas isso não tira a validade e a amplitude das conclusões.

Em conversa recente com o professor Gérard Vergnaud, ele me contou uma história interessante sobre nosso mestre. Em um dos inúmeros debates com a chamada escola americana de psicologia, alguém interpelou Piaget dizendo que a quantidade de entrevistados era muito pequena para a amplitude das conclusões e que, nos EUA, eles faziam grandes pesquisas, com inúmeros participantes. Utilizando análises estatísticas, eles chegavam a estimar correlações, tendências, etc....

Com a sabedoria de sempre, Piaget diz: um pequeno pedaço de carvão possui as mesmas características de uma tonelada de carvão.

Acho que é isso aí.

Um abraço. Gabriel Carvalho

\section{Em 08 de Novembro de 2012, Clélia Ignatius escreveu:}

Olá a todos

Essa conversa está cada vez mais interessante. Quando Gabriel indaga se o "bóson de Higgs" seria um objeto matemático, entendo que precisamos estabelecer o que estamos entendendo por "objeto matemático". Sabemos que 
para Piaget o objetivo da ciência é a conquista do objeto, e que este objeto existe independentemente dela, ainda que se modifique, como todos vem afirmando, à medida que esta conquista se processa, proveniente de uma crescente aproximação. Também já foi mencionado em nossas discussões que não é possível, todavia, estabelecer-se, quando se trata de construção do conhecimento, um limite bem definido sobre o que compete ao sujeito ou o que compete ao objeto. No caso da Matemática, apelo para ASTOLFI e DEELAY para destacar que o matemático constrói seus próprios objetos, enquanto que o físico ou o biólogo leva em conta um real que preexiste e resiste e que ele vai procurar explicar, mesmo que para isto lance mão de uma equação matemática ou mesmo de um modelo matemático. Entretanto, este modelo se distingue do conceito matemático puro, pois necessita "obedecer" a regras ou condições que permitam estabelecer, pelo menos, uma correspondência com os objetos reais ou, mesmo, objetivos do universo. Para Piaget, o problema central da epistemologia reside no fato de ser possível uma ciência (no caso a Matemática) que se desenvolve com absoluta independência do real, ao passo que se adapte a ele. Na Matemática, mesmo o matemático atua, quase sempre, com representações dos objetos que são quase sempre abstrações bem complexas, desvinculadas do mundo real. Creio que nisto reside a beleza da Matemática e evidencia o que tentei chamar a atenção quando falei no tipo particular de interação que acontece "internamente - não sei dizer se Ao ou No - no sujeito". Porém, considerando a especificidade dos objetos matemáticos, e a obrigatoriedade dos modelos matemáticos de estabelecer correspondência com o real, em uma análise inicial, não entendo que o "bóson" poderia ser entendido como um objeto matemático. Certamente esta minha opinião poderá ser modificada conforme avancem as discussões.

\section{Clélia}

\section{Em 08 de Novembro de 2012, Gabriel Carvalho Junior escreveu:}

Olá. De fato, a conversa está muito boa!

Para botar lenha na fogueira, queria apresentar mais uma situação:

O bóson de Higgs existe de fato? Quer dizer, ele é uma entidade que "está aí", independente da nossa percepção? Ou, do contrário, ele é um modelo que funciona bem para explicar (descrever?) o comportamento verificável da matéria?

Se a resposta à primeira pergunta for "sim, ele existe de fato", temos, então, que admitir que ele represente a explicação definitiva da natureza. Nesse contexto, todos os que produziram explicações anteriores sem a colocação do bóson de Higgs erraram. Mas, nesse caso, fica a pergunta: em que o conhecimento da existência do bóson de Higgs é operacional para resolver problemas de, 
digamos, um bioquímico? Ou de um engenheiro civil? Para eles, o modelo de Dalton já é suficiente - e eles produzem belas coisas sem erro.

Se a resposta for "não", ou seja, o "Higgs" é uma criação, um modelo explicativo que não tem a obrigação de descrever o real; temos, então, que posicioná-lo na mesma categoria das construções dos objetos matemáticos. Isso significa dizer que ele é um modelo tanto quanto, por exemplo, um número negativo. Eu acredito que as explicações em Ciências da Natureza sejam, no fundo, modelos descritivos que, mesmo tendo alguns fenômenos naturais como referência, ainda assim não tem o compromisso (ou a necessidade) com o real.

Um pequeno exemplo: quando Riemman começou a estudar outras formas de geometria não baseadas no plano (como havia feito Euclides), seu estudo não possuía o compromisso com o real. As geometrias ditas não-euclidianas eram tidas como um exercício puramente teórico de exploração dos limites do raciocínio lógico-matemático. Mas, no começo do século $X X$, Einstein se utiliza exatamente dessas construções como a base do seu universo quadridimensional e somente dessa forma conseguiu um contexto para a Teoria da Relatividade Geral. Esse espaço foge a nossa percepção imediata.

Mas, houve uma interação entre sujeito e objeto matemático. No caso, percebemos tanto a modificação nas estruturas pessoais no sentido de acomodar essa nova - e um pouco estranha - forma de conceber o universo quanto no próprio objeto matemático que passou a ter um estatuto de estrutura do universo habitável.

Com minha escassa experiência na Epistemologia Genética, ouso dizer que o trabalho de Piaget e Garcia, nos anos 70, estava orientado nesses termos.

Aproveitando o ensejo, gostaria de dizer que estou em estágio sanduíche nos Archives Jean Piaget, pesquisando sob a orientação da Professora Silvia ParratDayan, a evolução do conceito de esquema na obra de Piaget. Uma parte importante para meu trabalho é verificar como esse conceito é percebido pelas pessoas que trabalham na perspectiva piagetiana. Dessa forma, se não for muito incômodo, gostaria de pedir aos participantes da lista que descrevessem o que entendem por esquema (schème) no contexto da Psicologia Genética e quando, na concepção de cada um, esse conceito começou a ser utilizado por Piaget. Agradeceria enormemente se as contribuições fossem enviadas para o meu email ifmgabriel@gmail.com .

Obrigado a todos pela oportunidade. Abraços. Gabriel Carvalho

\section{Em 08 de Novembro de 2012, Alexandre Ferraz escreveu:}

Olá a todos. Tendo a concordar com Clélia sobre os objetos matemáticos. 
Embora a gente não possa ver o bóson de Higgs, tampouco perceber qualquer interação com ele, conforme nos disse Gabriel, e só porque tal partícula acaba sendo o resultado de um conjunto de modelos matemáticos que guardam coerência lógica interna, não quer dizer que tal partícula se torne um objeto tal como o matemático.

Isso me lembra diretamente, em Filosofia, a corrente fisicalista. Alguns materialistas não conseguiram (ou não conseguem, quando em debate), eu penso, explicar que a composição dos objetos do mundo é puramente material, inferindo uma ontologia não metafísica (ou física), uma vez que nós sabemos da existência de partículas cada vez menores que interagem entre si, mas tais partículas são físicas, donde a opção pelo fisicalismo como ontologia (também não metafísica), neste sentido.

Existem, ainda, algumas pessoas que têm defendido uma filosofia num plano informacional (e talvez auto-organizado), isto é, relacional, onde os objetos, cada vez menores (partículas, tal como o bóson), existem enquanto interagindo um com o outro e é justamente essa relação que estipula os aspectos epistemológicos e ontológicos, uma vez que, aí, "tudo é relação", mas não pressupõe questões metafísicas.

Na Epistemologia Genética (me corrijam, por favor, caso necessário) os objetos matemáticos "puros" não são assimilados dos objetos, pois o que se assimila dos objetos materiais são propriedades deles mesmos (peso, cor, altura, enfim). Falo aqui de uma matemática abstrata, onde seus objetos são assimilados das relações que o sujeito estabelece entre eles: daí o período operatório concreto, uma vez que estabelecer classes e relações não é simplesmente interagir com o objeto físico (embora ainda diretamente a ele ligado), mas elaborar classificações e seriações (relações) segundo as propriedades dos objetos. Veja que essas relações (que serão classificações, seriações, funções, números, estruturas lógico-matemáticas, etc) são os objetos pelos quais nós estamos falando e, portanto, não tem uma instanciação fisicalista, a menos por abstração empírica do objeto material, onde eu abstraio certa propriedade de tal objeto e a relaciono (agora a matemática) com outros por suas equivalências, integrações e diferenciações. Mais ainda, quando, no operatório formal, o sujeito é capaz de operações sobre operações, aí que as propriedades matemáticas (e consequentemente seus objetos) se distanciam de qualquer instanciação física do mundo. Embora eu ache que isso não é segredo para ninguém.

Nunca agimos materialmente (a menos contra nossa vontade) com a eletricidade, ou com ondas eletromagnéticas, mas elas estão aí e se diferenciam significativamente dos objetos matemáticos, que são abstrações meramente. A eletricidade física pode ser abstração para construção de modelos, como o bóson ou quaisquer partículas atômicas ou subatômicas. Mas não há de se 


\section{Ş̉hème \\ Revista Eletrônica de Psicologia e Epistemologia Genéticas}

negar que um ente físico provoca sensações em nosso corpo. Os matemáticos não (no mesmo sentido que os físicos). E isso muda completamente a ontologia (natureza) destes entes.

Esses objetos matemáticos, por fim, poderiam dizer, têm outra ontologia (metafísica, inclusive). Se você perguntar a um neo-platonista, por exemplo, ele vai dizer que tais objetos residem num mundo atemporal, sem espaço, porque, ao analisar o comportamento de uma função, quer dizer que você analisa uma coisa que, por necessidade, deveria existir antes, caso contrário, não é possível tal análise. Onde ela reside se não neste mundo? Só pode haver outro, donde o neo-platonismo, grosso modo.

Como disse Clélia, posso mudar minha opinião, caso eu esteja muito errado (e, inclusive, pediria desculpas). O que quis evidenciar é que a natureza (no sentido de "a ontologia") desses objetos é distinta. Uma é física, a outra é metafísica (eu tendo a pensar que esse metafísico não pressupõe outro mundo, mas uma ideia como simples operação do pensamento, característica particular dos seres-humanos, ou, em último caso, um sistema conceitual humano que não é um ente físico). Alexandre Ferraz.

\section{Em 08 de Novembro de 2012, Gabriel Carvalho Junior escreveu:}

Olá mais uma vez. Alexandre, muito obrigado pelas suas colocações. A questão das ontologias diferentes é muito importante para pensarmos na construção de um sistema conceitual coerente.

Essa discussão é muito interessante e proveitosa.

O que posso dizer para contribuir um pouco com o debate é:

As partículas da Física subatômica existem de fato ou são construções teóricas coerentes com os fatos observados? Dito de outra forma: um físico de cordas, por exemplo, aprende a chamar de partícula um determinado comportamento de um conjunto de equações escritas em um sistema de 11 dimensões. Ele está assimilando propriedades advindas de um mundo puramente conceitual (talvez o que Popper chamou de "mundo 2") e acomodando a um sistema (prefiro o termo "sistema" ao de "estrutura") formal próprio. A necessidade de referências dos objetos físicos é tão intensa que, para citar um exemplo simples, as propriedades das partículas recebem nomes como "sabor" e "cor", apesar de não haver qualquer relação com o que entendemos por sabor e cor.

Por isso, a minha dúvida é: do ponto de vista do sujeito cognoscente, qual é o limite (ou quais são os limites) entre os objetos físicos e matemáticos se não há, em essência, limites definidos entre sujeito e objeto? 
Abraços, Gabriel Carvalho

\section{Em 12 de Novembro de 2012, Ricardo Tassinari escreveu:}

Olá Fernado, Gabriel, Patrícia, Clélia, Alexandre e demais membros da lista.

Concordo também, no geral, com as observações da Clelia. Em relação aos Bósons de Higgs, entendo que, como ela disse, segundo a concepção de Piaget, podemos dizer que a noção de bósons de Higgs surge na medida em que construímos teorias para explicar a realidade (realidade que existe independente de nós); assim, pelas teorias estarem explicando a realidade física, apesar dessas teorias se utilizarem da Lógica e da Matemática, os bósons não são objetos matemáticos: é suposto (pela teoria que tem algumas de suas predições confirmadas pela experiência) que eles existam na Natureza (até uma teoria melhor mostrar que essa suposição é falsa e propor outra melhor).

Para se compreender melhor as relações entre as matemáticas e a realidade, segundo Piaget, vale a pena ver o Item C da Seção II do Capítulo III do livro A Epistemologia Genética, bem como o Item C da Seção III do mesmo capítulo, que dão base à reflexão acima.

Gabriel: você estava perguntando sobre uma possível visão de Piaget sobre o assunto ou estava buscando novos horizontes quando colocou a questão: "As partículas da Física subatômica existem de fato ou são construções teóricas coerentes com os fatos observados?".

Voltando à questão do status do objeto matemático...

Fernando: gostei muito de sua solução. Penso que sua colocação (que reproduzo abaixo) a resume:

Nós não podemos interagir com os objetos matemáticos; nós apenas podemos agir sobre eles. Se houver interação será entre nós e eles. Interação é um substantivo que designa duas ações, ao mesmo tempo opostas e complementares, que produzem um tertium; ações do sujeito $\boldsymbol{e}$ do objeto.

Mas eu não entendo quando você diz (no início de seu e-mail) "assimilamos objetos matemáticos", pois a noção de assimilação parece exigir algo para se assimilar; e esse algo tem que existir antes da assimilação. Para Piaget, no caso dos objetos matemáticos, existe uma "construção efetivamente constitutiva" desses objetos (ver a última das citações acima do A Epistemologia Genética). Suponhamos então que um objeto matemático resultou de uma construção; a partir daí poderia haver interação entre nós e ele, como diz você; mas podemos então nos perguntar: nesse caso, haveria assimilação de quê? De suas propriedades formais? Mas essas são o resultado da própria construção 


\section{Ş̉hème \\ Revista Eletrônica de Psicologia e Epistemologia Genéticas}

realizada pelo sujeito; assim, dizer que existe assimilação não me parece adequado.

Mas aí surge o problema: teríamos então nesse caso interação sem assimilação?

Concordo com você que "temos que produzir numerosas e sucessivas modificações em nossos esquemas assimiladores, para dar conta das múltiplas dificuldades que esses objetos põem à nossa compreensão". Concordo, pois o sistema de esquemas de assimilação é condição para que algo tenha significação para o sujeito; mas me parece que o termo "assimilação" neste caso se refere a que esses esquemas assimilam outras coisas e não propriamente os objetos matemáticos.

A dificuldade parece surgir de que a noção de interação/adaptação das estruturas cognitivas, tal como caracterizada por Piaget em termos de assimilação e acomodação, foi construída (por Piaget) a partir de uma analogia (muito feliz) com a Biologia; mas essa analogia exige a (pré)existência de objetos (ou propriedades) a serem assimilados, o que choca com o anti-platonismo piagetiano.

Parece-me que, no caso dos objetos matemáticos, existe assimilação reciproca entre diversos esquemas, o que permite entender a interação proposta por você entre nós e o objeto matemático, pois o objeto matemático exige essas assimilações (e acomodações) para chegarmos à compreensão de suas propriedades; mas não há assimilação (propriamente dita) do objeto matemático ou de suas propriedades; esses parecem muito mais ser o resultado de acomodações (em maior grau) do que de assimilações.

O que me diz?

Gostaria também de ouvir o que a Clelia tem a dizer a respeito.

Abraços, Ricardo Tassinari

\section{Em 11 de Novembro de 2012, Clelia Ignatius escreveu:}

\section{Olá pessoal, Olá Ricardo}

Logo que li sua resposta (e provocação) não sabia muito bem o que dizer. Vou concordando com o que você afirma até quase no final, quando você menciona:

Parece-me que, no caso dos objetos matemáticos, existe assimilação recíproca entre diversos esquemas, o que permite entender a interação proposta por você entre nós e o objeto matemático, pois o objeto matemático exige essas assimilações (e acomodações) para chegarmos à compreensão de suas propriedades; mas não há assimilação 
(propriamente dita) do objeto matemático ou de suas propriedades; esses parecem muito mais ser o resultado de acomodações (em maior grau) do que de assimilações.

Fiquei pensando muito nisso. Devo dizer que de imediato concordei. Mas fiquei buscando como poderíamos justificar tal afirmação.

Infelizmente, não estou em minha casa (já faz quase uma semana!) e não posso recorrer aos meus livros (particularmente: Lógica e conhecimento científico; Epistemologia matemática e psicologia; Epistemologia Genética e Introdução à Epistemologia Genética - 1: O pensamento matemático, que são os principais trabalhos de Piaget acerca da Epistemologia da Matemática), então conto com minha memória e a alguns fragmentos constantes em slides de aulas de Epistemologia das Ciências ministradas há algum tempo.

Penso que o grande problema se encontra nos "objetos" matemáticos. Porém estes não possuem caráter ontológico, pois mudam constantemente de função à medida que mudam de nível, isto é, uma operação que recai sobre determinados "seres", converte-se, por sua vez, em objeto de teoria, num outro patamar (abstração reflexionante), e assim, sucessivamente, de forma que tudo pode tornar-se um "ser", dependendo do estágio em que está sendo analisado. Ditos de outra forma, os objetos matemáticos, à medida que mudam de nível, mudam de função, de modo que determinados objetos matemáticos, ao deixarem de ser considerados isoladamente, passam a ser estudados como estruturas em função do relacionamento existente entre eles (por exemplo, os números inteiros, ao serem estudadas as relações existentes entre eles, dão origem ao Anel dos Inteiros), porém, essas estruturas, convertem-se, em outro patamar, em objeto de teoria (o Anel dos Inteiros é um objeto de estudo da Teoria dos Grupos); e assim sucessivamente, de forma que tudo pode tornar-se um "ser", dependendo do estágio em que está sendo analisado.

Mas, mesmo que para esta nossa conversa não estabeleçamos diferenças entre "ser" e "estrutura", enfim, que enfoquemos simplesmente as interações entre nós e os "objetos" matemáticos, da maneira proposta por você (e concordando com isto) isto é, de que essas parecem muito mais ser o resultado de acomodações (em maior grau) do que de assimilações, poderíamos justificar esta afirmação considerando o que Piaget entende como um dos "problemas epistemológicos" da matemática, a saber, o fato de se impor de maneira necessária, permanecendo rigorosa, apesar de seu caráter construtivo? Seria esta "necessidade", esta certeza de que as conclusões, por ser dedutivas, "só poderiam ser desta maneira", apesar da fecundidade da construção matemática que justificaria a primazia das acomodações na interação entre sujeito e objeto matemático?

O que vocês acham? E você, Ricardo? Abraços, Clélia 


\section{Em 19 de Dezembro de 2012, Ricardo Tassinari escreveu:}

Olá Clélia e pessoal.

Gostaria de colocar mais um elemento em nossa discussão (Desculpem-me o atraso... é final de semestre).

Quando aprendemos Matemática (na escola, por exemplo), aprendemos a operar sobre signos.

Por exemplo, escrevemos

$2+3$

e, abaixo,

5

Ora, existem as (3) ações de escrever:

2

$+$

3

e depois a ação de escrever

5

Claro que essa conta só será significativa, se o sujeito atribuir significados a esses signos (portanto, não se trata aqui de um nominalismo); mas, o que quero enfatizar é que a coordenação dessas ações está diretamente relacionada às estruturas operatórias e às estruturas matemáticas (por exemplo, as operações sobre os signos acima [numerais], está diretamente relacionada às operações entre os números correspondentes). Assim, parece-me que a compreensão das estruturas matemáticas está diretamente relacionada a essas ações/operações sobre signos: é através delas que o sujeito toma consciência das propriedades formais das estruturas matemáticas em questão. $\mathrm{E}$ isso, inclusive, para $\mathrm{o}$ matemático que faz Matemática de ponta.

Nesse sentido, temos uma continuidade do sistema de ação em um sistema de ações e de operações (no Período Operatório Concreto e depois no Operatório Formal), ou seja, nestes períodos, ora a ação do sujeito se dá externamente ora internamente, mas, na maioria da vezes, se dá nos dois domínios ao mesmo tempo. 


\section{Ş̉ithème \\ Revista Eletrônica de Psicologia e Epistemologia Genéticas}

Voltando à questão da ação/operação sobre signos, na medida em que se nomeiam (com signos) as propriedades formais (como por exemplo, "comutatividade", "associatividade", etc., ou mesmo com as fórmulas que as representam) e se operam sobre elas, o sujeito as transforma de forma em conteúdos (como você sublinhou em seu e-mail).

Concordo então com você (Clélia) quando diz a esse respeito que "[...] tudo pode tornar-se um "ser" [...]" e aí está para mim uma das principais chaves para se entender o que é o objeto matemático: o objeto matemático é, ao mesmo tempo, forma e conteúdo. Tomemos por exemplo o conjunto dos números naturais $\mathrm{N}=\{0,1,2,3$, etc. $\}$; ao mesmo tempo ele serve de forma (por exemplo, para responder quantas ocorrências de caracteres temos neste e-mail) e de conteúdo (pois estamos falando sobre eles). O objeto matemático indica uma forma de coordenação de ações/operações, por exemplo, o número 3 atribuído a dois conjuntos diferentes, indica a possibilidade de correlacionar biunivocamente os elementos desses conjuntos. Assim, o objeto matemático é uma forma (-conteúdo) de coordenação e, por isso é tão geral (e se aplica necessariamente ao conhecimento físico).

Quanto à necessidade dos seres matemáticos, isso para mim insere um problema cuja resposta eu não consigo visualizar completamente, se nos atermos ao anti-platonismo piagetiano. Dizer que as ações tendem necessariamente a certas formas de coordenações (e, portanto a esses objetos matemáticos, como descritos acima) significa, a meu ver, dar subsistência a essas formas de coordenações enquanto possibilidades, mesmo que pensemos (como Piaget) que essas possibilidades, para o sujeito, dependem do nível em que o sujeito está, pois um observador que já as conhecesse poderia dizer: "vejam, agora ele (o sujeito) vai tomar consciência da existência dessas formas matemáticas". É o paradoxo que vejo quando Piaget busca refutar a hipótese platonista dizendo:

Sem dúvida a hipótese platônica é irrefutável no sentido em que uma construção, uma vez efetuada, pode sempre ser considerada, por isso mesmo, ter sido eternamente predeterminada no mundo dos possiveis considerando-se este como um todo estático e acabado. Mas como esta construção constituía o único meio de acesso a tal universo de Ideias, ela se basta a si mesma sem que haja a necessidade de hipostasiar seu resultado.

Ora, se essa construção matemática não é apenas a de um sujeito psicológico específico (eu ou você) mas do sujeito epistêmico, ou seja, das possibilidades dos seres humanos, como recusar existência em termos de possibilidade a uma construção admitida como necessária?

Abraços, Ricardo.

Em 19 de Dezembro de 2012, Alexandre Ferraz escreveu: 


\section{Oi Ricardo (e Grupo).}

Sobre seu último e-mail, tendo a algumas considerações (pois tenho pensado isso em minha dissertação):

1. Parece-me que operações sobre signos é uma questão óbvia (se se trata da matemática abstrata de "mais alto nível"), uma vez que é preciso entender cada definição, cada teorema, cada resultado (proposição, fórmula, gráfico, etc.) que são dados em forma de conceitos (ou signos que representam conceitos e que torna a matemática cada vez mais abstrata). Logo, não é só o entendimento da palavra como conceito (no sentido piagetiano, diferindo do esquema-verbal, pré-conceito, etc.), mas também o entendimento e a operação dos (e sobre os) signos, cujo significado é o próprio conceito e, este último, por sua vez, também tem um significado (que às vezes é bastante diverso do utilizado na matemática).

Um exemplo: Um signo * pode indicar uma composição de deslocamentos de signos $\mathrm{AB}$ e $\mathrm{BC}$ (deslocamento de $\mathrm{A}$ até $\mathrm{B}$ e de $\mathrm{B}$ até $\mathrm{C}$, respectivamente). $\mathrm{O}$ sujeito que entende a estrutura matemática "composição de deslocamentos" deve entender ou operar, então:

a. O signo * sabendo os tipos de composições possíveis, o que ele de fato representa (uma composição de deslocamentos e, portanto, é um operador);

b. Os signos A, B, C e AB, BC (de novo entendendo o que cada um representa, qual a possibilidade de interação (operação) entre eles, quais os resultados possíveis);

c. O significado do conceito asterisco, independente do uso dele na estrutura matemática.

Poderíamos continuar com várias formas de significação e, portanto de operações sobre os símbolos (que nas estruturas matemáticas seu significado é um conceito: * é o símbolo [ou signo] que representa o conceito "operação de deslocamento", mas asterisco também significa outra coisa em outro lugar, momento, etc.).

Portanto, estou de acordo com você: mas me parece bastante óbvio que um sistema de operações sobre símbolos e signos seja necessário para o entendimento de estruturas matemáticas ABSTRATAS.

Minha questão é: é suficiente? E eu diria: absolutamente não.

Não estou falando, aqui, de um nominalismo porque, considerando o conceito piagetiano (sistemas de classes, isto é, conjuntos de objetos agrupados segundo 
relações de encaixes hierárquicos (parte e todo), bem como sistemas de relações particulares agrupadas segundo sua natureza assimétrica ou simétrica ( $A$ formação do símbolo na criança, p. 281)) já estou pressupondo um conceito operatório tal que sua constituição dependeu da construção de longa data e ainda pré-operatória, após longo período de esquemas verbais e pré-conceitos (com transduções, etc.), após o fim do sensório-motor e do começo da função semiótica.

Há algo mais, em minha opinião: como posso entender o teorema de Gödel, as equações diferenciais ordinárias, o cálculo diferencial e integral? Há alguns elementos que pedem algo mais do que operações sobre signos (há pessoas que simplesmente não entendem tais estruturas e seria muito infeliz de minha parte dizer que isso não pode ser revertido, já que as estruturas necessárias para o conhecimento científico tais pessoas possuem e, inclusive, em outras áreas, essas pessoas as utilizam de forma admirável).

2. Ainda, pensando na resposta sobre a insuficiência das operações sobre signos, faço algumas perguntas: Como posso afirmar (com plena certeza), como o fez Piaget (1967, 1989, p. exemplo) que as raízes das estruturas matemáticas estão no sensório-motor? Já vimos que o GPD não é um Grupo Matemático. Ora, como então a criança entende os Grupos Matemáticos? Ela pode vir a fazer operações sobre signos. Mas como afirmar que a raiz disso é sensório-motora? Já que Piaget afirmou, sem ter consciência de que o GPD, por exemplo, não era um Grupo Matemático.

Outro exemplo: qual a garantia dessa citação?:

Quando um bebê levanta uma cobertura, sob a qual se tinha colocado um relógio e percebe um chapéu (que se tinha escondido lá, sem que ele soubesse e sob o qual se colocou o relógio) levanta, imediatamente o boné, esperando aí encontrar o relógio. Compreende então, através da ação, uma espécie de transitividade das relações que se poderia exprimir em palavras: "o relógio estava sob o chapéu, o chapéu sob a cobertura, donde o relógio está sob a cobertura". Tal transitividade das ações constitui o equivalente funcional do que será, no plano representativo, a transitividade das relações seriais ou a dos encaixamentos topológicos e mesmo das inclusões de classes. (Piaget, 1963, p. 88)

Primeiro: como avaliar esse equivalente funcional? Pelo processo de assimilação (recíproca, inclusive)? Como garantir que a transitividade, enquanto operação de pensamento, tem uma raiz sensório-motora? $O$ que garante ser essa a resposta e não outra?

Tudo isso para perguntar: $\mathrm{O}$ que é o prolongamento da estrutura mental em relação a estrutura orgânica? Por que as estruturas matemáticas são estruturas 
mentais, e estas últimas são um "prolongamento" das estruturas orgânicas? Esse "é" da pergunta é, inclusive, um "é ontológico".

3. Há uma corrente que estuda os objetos matemáticos que diz: a matemática nada mais é do que um sistema conceitual humano. Por isso ela: i) depende de nós enquanto humanidade (sujeito epistêmico, eu compararia) e por isso é objetiva no sentido que sua construção histórica a criou no que é; e ii) independe de nós enquanto indivíduos, mas há possibilidade de seu acesso enquanto há possibilidade do acesso ao sistema conceitual humano que ela é: aí não implica uma transcendência para um mundo platônico, se pensarmos esse sistema conceitual (o que inclusive pode vir a ser as operações sobre signos que tratou) como resultado das operações do pensamento, tal como queria Piaget, por exemplo, ou ainda, como um sistema de conceitos à la Piaget no sentido de um sistema de classes e relações, como disse anteriormente. Não implica, por isso, uma forma pura que necessite ser platonista, com implicações de ascendência (e existência) em um mundo que não este, mas que admita que sua constituição seja puramente metafísica (no sentido que não é física) e que é nossa ontologia geral.

Preciso só pensar sobre a insuficiência do sistema de operações sobre signos com mais clareza.

Tentei ser mais claro neste e-mail. Desculpem-me o tamanho e desculpe-me, também, se houver algum erro. Peço, como sempre (o que nunca há), correção.

Abraços.

\section{Em 19 de Dezembro de 2012, Ricardo Tassinari escreveu:}

Oi Alexandre. Resposta rápida:

- Como argumentei no e-mail anterior, as operações (e também as estruturas matemáticas) organizam o sistema de ações (como as ações de escrever $2+3$ e daí 5), nesse sentido são o prolongamento do sistema de (esquemas de) ações.

- A coordenação das ações (presentes em 2 + 3 e 5, desculpando a simplificação) começa no sensório-motor (como você muito bem sabe). Apenas, essas coordenações são parciais e no caso das estruturas mais usuais em matemáticas elas têm mais Gestalt, isto é, leis simples que geram muitos resultados.

- As ações tem base biológica, ou seja, decorrem do funcionamento de um organismo; nesse sentido, as ações mais complexas (com base nas operações sobre símbolos e signos), ainda decorrem do funcionamento do organismo, nesse sentido, são o prolongamento do funcionamento de uma estrutura mental biológica. 
- Sistema de operações sobre signos são suficientes? Sim e Não.

Não se você considerar que as verdades aritméticas (e, portanto matemáticas) não são redutíveis a um único sistema axiomático (Teorema de Gödel).

Sim, se você considerar que signos podem designar qualquer coisa (e qualquer coisa pensada pode ser designada por um signo) e que estrutura abstrata de qualquer coisa pode ser representada por uma estrutura de signos; mas é importante notar que, nesse caso, o sistema de signos, ou melhor, o sistema de significações não é mecânico; no caso de Piaget, o funcionamento orgânico ultrapassa o funcionamento mecânico.

- Quanto ao platonismo, de forma rápida, por exemplo, acho estranho pensar que a humanidade (ou qualquer outra espécie com inteligência comparável a do homem) depois de se representar as quantidades (números) e suas operações mais gerais não viessem a chegar a tomar consciência da estrutura de grupos, ou pior, criaria outras estruturas que não tivessem nada a ver (isomorfismo) com as estruturas que estudamos hoje em dia.

Abraços, Ricardo.

\section{Convergências}

Os que acompanharam o debate sobre o tema da interação em Epistemologia Genética poderão identificar momentos de convergência entre os debatedores, pelo menos em alguns pontos. Destacaremos, em forma de itens ou afirmações, as convergências mais gerais; em seguida nos arriscamos a tecer, em alguns itens, breves explicitações e comentários.

- Não há consenso a respeito do significado do conceito de interação na Epistemologia Genética.

- O conceito de interação nem sempre é utilizado corretamente. Costumase priorizar, erroneamente, apenas um dos polos da relação, em geral o polo do sujeito, pois atende ao egocentrismo do observador, em detrimento da "ação" do objeto sobre o sujeito. 
- A interação caracteriza-se, essencialmente, pela relação sujeito-objeto no processo de construção ou estruturação de todo conhecimento, seja físico, lógico-matemático, social, moral...

- Interação não se aplica só ao que vem de fora, do meio. É pequena a convergência, neste debate, de que ela se estenda às assimilações mútuas de esquemas, de subsistemas de esquemas e de sistemas de esquemas dando origem a novas estruturas.

- Tende-se a caracterizar como objeto somente o que é acessível pela experiência física ou pela abstração empírica. Não é generalizada a convergência entre os debatedores no sentido de que tudo o que é "não sujeito"é objeto passível de ser assimilado. Um modelo matemático, um conceito físico, uma teoria filosófica são objetos a assimilar.

- O conceito de interação é de fundamental importância para compreendermos a Epistemologia Genética. Este conceito está intrinsecamente relacionado com os processos biológicos gerais, isto é, com as invariantes funcionais biológicas chamadas de "adaptação" e "organização" do sujeito-organismo que se manifestam como assimilação e acomodação. Estes processos darão, por sua vez, condições essenciais para o surgimento do sujeito epistêmico e, por conseguinte, tornará possível a Epistemologia Genética, já que o sujeito epistêmico é, como sabemos, seu objeto de estudo.

- A interação é uma troca entre os polos em questão que tendem, com maior ou menor probabilidade, ao equilíbrio. Troca possível pela atividade assimiladora do sujeito. A assimilação é o fato fundamental. Todo organismo tende ao equilíbrio entre os fatos internos e externos ou, de modo mais geral, entre a assimilação e a acomodação. 
- O conceito de interação envolve a indissociabilidade entre organismo e meio, entre indivíduo e sociedade, entre sujeito e objeto. Porém, essa indissociabilidade somente adquire significação se considerarmos tanto a dimensão do "funcionamento" quanto a das "estruturações" sucessivas da organização pelo processo adaptativo.

- A ação exerce papel central na interação. Como a própria palavra "interação" indica, não se pode pensar a interação sem a ação entre os polos envolvidos, isto é, sem a "inter-ação" entre os polos. Em resumo: na interação está implicada a ação como condição sine qua non. Ação que, na medida em que se interioriza, transforma-se em operação, transformando, progressivamente, a capacidade assimiladora.

- A interação realiza-se em diferentes níveis. Podemos falar em interação química, física, biológica, psicológica, social, epistemológica, educacional, etc. Por exemplo, no nível químico dizemos que as substâncias interagem, no físico dizemos que os corpos interagem, no biológico falamos em interação entre o organismo e meio, no psicológico falamos em interação entre indivíduos, no social falamos, por exemplo, em interação entre normas e padrões sociais construídos pelos sujeitos ou interação entre instituições, no epistemológico dizemos que sujeito e objeto interagem. No caso do sujeito epistêmico, interesse da Epistemologia Genética, podemos dizer que ele engloba cada um dos níveis anteriores, pois os níveis químico, físico, biológico, psicológico e social são condições para sua existência como sujeito epistêmico (já que este sujeito não é um sujeito transcendental, mas um sujeito que tem uma história que remonta às suas bases biológicas). Assim, podemos dizer que a indissociabilidade entre sujeito e objeto, entre organismo e meio, se torna mais clara dependendo do nível de análise em que nos encontramos. 
- A interação apresenta (ou parece apresentar) traços semelhantes a um movimento dialético. Embora haja muitas concepções de dialética, em diferentes filósofos, podemos dizer que o esquema básico do método dialético são a tese (uma ideia de algo inicial), a antítese (uma ideia desse algo oposta à ideia inicial desse mesmo algo) e a sintese (uma ideia desse algo resultante da oposição entre tese e antítese, mas que carrega dentro de si novos elementos). Nesse sentido, podemos notar semelhanças com os processos biológicos e cognitivos da interação, tal que a tese se assemelharia aos esquemas que consideramos iniciais (processo de assimilação), a antítese se assemelharia às restruturação dos esquemas frente aos novos desafios (processo de acomodação), e a síntese se assemelharia à estrutura mais adaptada (resultante do processo de adaptação, que é o equilíbrio (temporário) entre a assimilação e a acomodação). O processo adaptativo ocorre em termos de interação entre os esquemas de ação (esquemas hereditários ou adquiridos - na nossa compreensão, os esquemas cognitivos são todos adquiridos; os primeiros esquemas, evolução dos reflexos, aparecem por volta dos 4 meses; são caracterizados por serem repetitivos, recognitivos e generalizadores - $\mathrm{o}$ que não se pode atribuir aos reflexos) e o meio. A adaptação cognitiva prolonga, por restruturações, a vida orgânica. Cabe observar, aqui, que a adaptação no plano dos primeiros esquemas de ação tem algo de comum, embora as grandes diferenças, com o processo de adaptação no plano do conceito e da prática científica.

\section{Divergências}

O leitor que acompanha este Debate pode perceber não poucas divergências entre os debatedores. Nesta seção tentaremos traçar, mesmo que em linhas gerais, o que consideramos serem os principais pontos de divergência. 
- A primeira grande divergência que encontramos no Debate decorre de tentativas de responder à questão: seria a precária ou a equivocada compreensão do conceito de interação que conduziu, ou conduz, ao fracasso a aplicação, governamental ou não, do construtivismo nas escolas? Uma primeira hipótese apresentada é de que o problema não está no entendimento do conceito, mas em um problema anterior: o problema do analfabetismo funcional dos professores. Outra hipótese diz que o problema não é apenas o do "analfabetismo funcional", mas de como chegam os conceitos e a teoria até os professores.

- No debate houve outro ponto de divergência que surgiu a partir da seguinte questão: “Será que o sujeito e o meio têm o mesmo peso na interação?". Uma primeira posição defende que sujeito e objeto têm o mesmo peso na interação e outra posição defende que sujeito e objeto não têm o mesmo peso na interação, pois, neste caso, a interação se deslocaria mais para o lado do sujeito, por assim dizer.

- Outra divergência diz respeito à abrangência da ação. Alguns restringem a ação à experiência física ou abstração empírica. Outros avançam um pouco além, mas não conseguem integrar todo agir humano nesse conceito fundamental, subsumido pela interação. Para Piaget, ação abrange desde o olhar, o agarrar e o sugar da mamadeira, pelo bebê de quatro meses, até as operações mais sofisticadas dos cientistas, filósofos, literatos, etc. Abrange, pois as ações dos cientistas do CERN, com o LHC, amplamente referido neste debate a propósito do bóson de Higgs. Ação abrange desde o ato de quase pura materialidade do bebê, até os atos de quase pura consciência do cientista, do filósofo, do místico, do poeta... É por isso que utilizamos pouco a palavra ação e abusamos da palavra interação. Não basta haver ação, para que haja interação. $\mathrm{O}$ sujeito age sobre algo, material ou 
formal. Se não receber resposta desse algo, não poderemos ainda falar de interação. Só haverá interação quando o sujeito receber uma resposta do mundo do objeto (coisa, conceito, noção, teoria, interlocutor, sociedade, etc. etc.), resposta que o desequilibra e que, ao encará-la, produz alguma coisa nova - nem que seja apenas no seu âmbito individual, resultado de acomodação.

- Alguns debatedores entendem que o processo interativo resulta sempre em equilíbrio. Afirmamos a respeito que o equilíbrio nunca é necessário; ao contrário, é contingente, histórico. Um indivíduo pode não estar disposto a assumir o ônus de uma acomodação - o equilíbrio resultante será frágil ou quase inexistente. Ao contrário, um indivíduo poderá assumir o ônus da acomodação e envidar todos os esforços possíveis, além de contar com um meio prestativo e colaborador e, assim, atingir um patamar de equilíbrio de grande envergadura.

- Algum debatedor afirmou que a interação é um tipo de relação científica, explicativa das relações entre fenômenos. Afirmamos que isso não exclui que se trata de um tipo de relação que caracteriza todo o processo de construção do sujeito epistêmico.

Entendemos que as divergências entre pontos de vista dos debatedores, no sentido de confrontação mais direta de teses ou posições, estão mais claramente apresentadas nos itens que elencamos acima.

Parece-nos que o debate mudou de "tom" quando foi colocada a questão: “Interagimos com objetos matemáticos?” A partir de então, o debate se tornou mais especulativo, se assim podemos dizer, e as posições dos debatedores não foram, propriamente, de discordar ou concordar, mas de apresentar hipóteses, de modo construtivo, de acordo com o movimento do debate e das questões que foram surgindo a partir dessa questão. 


\section{Sthòme \\ Revista Eletrônica de Psicologia e Epistemologia Genéticas}

Tentemos discriminar, em forma de itens, os problemas e afirmações que essa questão substantiva nos coloca, ao lado de tantas outras questões:

- Não se reconhece o conhecimento matemático, um modelo matemático ou um modelo científico (bóson de Higgs) como objeto, e, como tal, passível de assimilação.

- Tende-se a não caracterizar como objeto resultados de experiências lógico-matemáticas ou abstrações reflexionantes (o bóson de Higgs “está aí" ?; há interação entre o sujeito e os objetos matemáticos?).

- Aceitam-se acomodações sem assimilações - no caso da construção de objetos matemáticos (como diz um debatedor:"...mas não há assimilação [propriamente dita] do objeto matemático ou de suas propriedades; esses parecem muito mais ser o resultado de acomodações [em maior grau] do que de assimilações.")

\section{Questões remanescentes}

O que consideramos "remanescentes" são questões centrais para o tema da interação que foram levantadas pelos debatedores durante a discussão. Acreditamos que tais questões precisam ser melhor exploradas para que possamos compreender mais a fundo este tema.

- No nível das relações escolares, em particular da relação professoraluno, podemos nos perguntar: não será a precária ou a equivocada compreensão do conceito de interação que conduz ou conduziu ao fracasso a aplicação, governamental ou não, do construtivismo nas escolas?

- Como compatibilizar o fazer ciência com a noção de que sujeito e objeto são inseparáveis? Pensamos que esta questão pode ser colocada nas 
seguintes palavras: se, sob a perspectiva da Epistemologia Genética, não existe mais aquela visão clássica de que o objeto existe separado do sujeito que o investiga, então como é possível, no fazer ciência, a objetividade científica?

- Sujeito e meio têm o mesmo peso na interação?

- Interagimos [ou agimos sobre os] com objetos matemáticos? Esta questão acarretou uma série de outras questões de Filosofia da Matemática, de Epistemologia e de Filosofia da Ciência. O que é um objeto matemático? O bóson de Higgs é um objeto matemático ou é uma construção de um modelo científico de base matemática? O bóson de Higgs existe de fato? Quer dizer, ele é uma entidade que "está aí", independente da nossa percepção ou, pelo contrário, ele é um modelo que funciona bem para explicar (descrever?) o comportamento verificável da matéria? Do ponto de vista do sujeito cognoscente, qual é o limite (ou quais são os limites) entre os objetos físicos e matemáticos se não há, em essência, limites definidos entre sujeito e objeto? Podemos dizer que assimilamos objetos matemáticos? Qual é o papel da assimilação e da acomodação na construção do objeto matemático? Como compatibilizar o caráter de necessidade dos objetos matemáticos com o anti-platonismo de Piaget?

- Para alguns debatedores, haveria assimetria entre assimilação e acomodação não apenas no sentido de uma acomodação insuficiente para responder à complexidade do objeto assimilado, mas no sentido radical, como no caso da construção matemática, em que haveria acomodação sem assimilação.

- O processo adaptativo na interação sujeito-objeto seria totalmente diferente do processo adaptativo na interação organismo-meio. Se for 
totalmente diferente, por que Piaget teria recorrido a esse processo para explicar o desenvolvimento do sujeito epistêmico?

\section{Comentários dos organizadores}

Nesta seção os organizadores tomam a liberdade de tecer comentários gerais sobre algumas das principias questões e afirmações abordadas no Debate. Seguem tais comentários listados em intens.

- Interação é um modelo de relação que rege todas as relações entre indivíduo e meio social (no plano psicológico), entre organismo e meio ambiente (no plano biológico), entre sujeito e objeto (no plano epistemológico).

- A dialética, cujo processo origina um tertium, nem sempre é reconhecida pelos debatedores.

- Afirma-se que o sujeito, tal como o organismo no qual se realiza, é um sistema aberto. O sujeito é um sistema aberto, mas o organismo, no qual se constitui o sujeito, é apenas parcialmente aberto - uma novidade na aprendizagem ou no pensamento é benvinda, uma novidade na reprodução celular pode trazer sérios problemas (tumores cancerígenos, p.ex.).

- No modelo piagetiano de desenvolvimento cognitivo, o conceito de interação condensa o significado do modelo de desenvolvimento cognitivo de Piaget. Isto é, organismo e meio, tal como indivíduo e sociedade e sujeito e objeto são indissociáveis, mas complementares; portanto distinguíveis. Nesse sentido, o conceito de modelo é idêntico ao que se utiliza na filosofia, na química, na física...; numa palavra, nas ciências (Cf. Piaget: modelo e estrutura, de Zélia R. Chiarottino). 
- Como compatibilizar o caráter de necessidade dos objetos matemáticos com o anti-platonismo de Piaget? Esta questão nos transporta ao âmago da Epistemologia Genética. Para Piaget, é a ação, compreendida como abstração reflexionante, que nos responde como se chega aos objetos matemáticos. No caminho da abstração reflexionante, o sujeito retira qualidades das coordenações das ações de um nível inferior de complexidade cognitiva, leva-as para um nível superior e, ali, reorganiza-as produzindo novidades, em nível de maior generalidade que nos níveis anteriores. É assim que do mundo dos possíveis chega ao conjunto de todo os possíveis; das contingências históricas chega ao necessário; agindo sobre entes finitos, chega ao infinito.

- Apesar do avanço, no sentido de se afirmar a indissociabilidade sujeitoobjeto, verificam-se resíduos arcaicos na concepção de "sujeito" e de "objeto". Ao afirmar-se que "o meio não tem o mesmo peso na interação" porque "o meio não tem a organização que o indivíduo tem", esquecem-se as organizações sociais e a própria complexidade do mundo físico (veja-se o que a ciência está fazendo para encontrar o sexto componente básico da formação o universo - o bóson de Higgs...). Piaget usa frequentemente um aposto para o termo "meio"; ao referir-se ao meio acrescenta - físico ou social. A concepção de meio, aparecida no debate, denuncia uma precariedade na concepção do que significa "objeto" na epistemologia piagetiana. Por exemplo, o conhecimento matemático, enquanto parte do "acervo cultural da humanidade" faz parte do mundo do objeto - que extraordinária organização exibe esse conhecimento! Algo parecido pode-se dizer do sujeito. O conteúdo do termo sujeito não é fixo nem volátil; é fluído, se assim pudermos nos expressar. Quando o sujeito se percebe parte do meio - físico ou social, do universo, o indivíduo percebe-se diminuto, quase absorvido pela 
complexidade do mundo; quando, porém, ele toma consciência da complexidade de seu organismo, de sua individualidade psicológica, da complexidade de seu pensamento e de sua consciência, o indivíduo sente-se agigantado como se o mundo estivesse nele sintetizado. É isso que queremos dizer ao afirmar que a relação sujeito-objeto não é fixa nem volátil, mas fluída. Decorre daí que o peso dos papéis de sujeito e de objeto na interação são, também, fluídos. Decorre daí, também, que falar em interação sem assimilação é propor o impossível, isto é, as construções do sujeito sem a participação do objeto, do sujeito sem a ocorrência do meio.

- Por isso, quando se afirma que interação sempre há, esquece-se que ela se dá numa graduação infinita, pois é histórica. Qual o professor que não sabe que, na sua turma de 35 alunos, meia dúzia compreende sua exposição antes mesmo de terminar a aula; outros 20 precisam de novas exposições, mais estudos, resolução de problemas; oito demandas tarefas redobradas; os restantes não conseguem assimilar o exposto nem repetindo uma, duas ou mais vezes a disciplina... Interação sempre há, mas em que nível de profundidade?

\section{Considerações finais}

Este debate nos ensina conhecimentos e valores sob muitos aspectos. Ensina-nos que é possível um debate saudável com vistas a convergências ou divergências. $\mathrm{O}$ debate aqui apresentado permitiu a muitos pesquisadores colocarem suas ideias, suas reflexões ou simplesmente acompanharem o debate sobre uma das questões centrais da teoria de Piaget.

O interessante de se publicar este debate, na Revista Schème, é aproveitar as contribuições que todos os participantes deram de modo que tais contribuições não se percam em nossas caixas de e-mails. Queremos que as 


\section{Sthòme \\ Revista Eletrônica de Psicologia e Epistemologia Genéticas}

ideias aqui apresentadas não caiam no esquecimento de modo que o tértium, resultante desta interação entre os debatedores, possa servir para motivar futuros debates ou futuras pesquisas.

Debates são muito comuns hoje em dia nas listas de discussões acadêmicas, mas pouco se tem aproveitado deles em citações de trabalhos acadêmicos. Aliás, como citá-los? Talvez com a publicação, como estamos fazendo aqui, torne mais viável citar tais contribuições em textos acadêmicos.

A partir deste debate podemos ter uma maior dimensão do que nós, pesquisadores da Comunidade do GPEGBrasil (comunidade composta por considerável soma de pesquisadores da Comunidade Piagetiana no Brasil e não poucos latino-americanos), temos em comum sobre temas importantes como o da interação; e tomar consciência das divergências e dos motivos dessas divergências. Sabemos, também, a partir de agora, sobre o que podemos progredir no conceito de interação e nos conceitos correlacionados, pois procuramos traçar, além dos principais pontos de convergência, os principais pontos de divergências; sem pretensão, é claro, de esgotar o tema e o debate como um todo.

Esperamos que este texto sirva de motivação para outros debates e quem sabe sirva como um texto de referência para futuras pesquisas ou até mesmo que este texto possa motivar um projeto coletivo que envolva os participantes do GPEGBrasil a estabelecerem pontos de convergência sobre outros temas em Epistemologia Genética; neste caso, por que não pensar, por exemplo, em confeccionar algo como um dicionário com o objetivo, inclusive, de publicação nos meios onde a teoria tem, como sabemos, grande potencial de aplicação, isto é, entre os profissionais da educação. Ou por que não pensar em algo mais ousado: elaborar um dicionário técnico ou um vocabulário comum entre nós pesquisadores? A proposta está lançada. 


\section{Sthìme \\ Revista Eletrônica de Psicologia e Epistemologia Genéticas}

A transcrição de debates virtuais para a forma escrita nos modos de publicação em uma revista de expressão, como é a Schème, resguarda a memória do debate. E como nós sabemos, a memória tem um papel fundamental na construção de uma identidade, seja esta identidade pessoal ou de ordem social (institucional), principalmente agora que nossa comunidade de piagetianos brasileiros, com participações de latino-americanos não brasileiros e europeus, está em processo de formação. Esperamos ter contribuído para que essa memória se constitua e se desdobre em muitas memórias.

\section{Referências}

Abaixo, as referências bibliográficas citadas ou sugeridas pelos debatedores durante o debate sobre o tema da interação:

APOSTEL, L.; MAYS, W.; W. MORF., A. PIAGET, J. Les liaisons analytiques et synthétiques dans les comportements $d u$ sujet. Paris: Presses Universitaires de France, 1957.

CLAUDE, B. J. Conversando com Piaget. Ed. Difel. Pode ser encontrado na Estante Virtual no seguinte link: http://www.estantevirtual.com.br/rinolivros/Bringuier-Jean-Claude-MariaJose-Guedes-trad-Conversando-Com-Piaget-61004205

COLL, C.; GILLIÉRON, C. Jean Piaget: o desenvolvimento da inteligência e a construção do pensamento racional. In: LEITE, L. B. Piaget e a Escola de Genebra. São Paulo: Cortez, 1987, p. 23-50.

HANS, J. G. H. Mead: A Contemporary Re-examination of His Thought (Studies in Contemporary German Social Thought). O livro pode ser encontrado no seguinte endereço: http://www.amazon.com/G-H-Mead-Contemporary-Reexamination $/ \mathrm{dp} / 0262600293 / \mathrm{ref}=$ sr 11 1? s=books\&ie=UTF8\&qid $=1350396500$ \&sr=1-1\&keywords=joas + mead

PIAGET, J. A epistemologia genética.

PIAGET, J. Biologia e conhecimento.

PIAGET, J. Epistemologia matemática e psicologia.

PIAGET, J. Lógica e conhecimento científico. 
PIAGET, J. Introdução à Epistemologia Genética.

PIAGET, J. O nascimento da inteligência na criança.

ROS, A. Materie und Geist: Eine philosophische Untersuchung. O livro pode ser encontrado no seguinte endereço: http://www.amazon.de/Materie-GeistEine-philosophische-

Untersuchung $/ \mathrm{dp} / 3897853973 / \mathrm{ref}=$ sr_1_1?ie=UTF8\&qid $=1350395741 \&$ sr $=8-1$

ROS, A. Die genetische epistemologie Jean Piagets: Resultate und offene Probleme. $\mathrm{O}$ livro pode ser encontrado no seguinte endereço: http://www.worldcat.org/title/genetische-epistemologie-jean-piagetsresultate-und-offene-probleme/oclc/464601567

Abaixo uma bibliografia sugerida pela professora Eliane Paganini sobre a questão do construtivismo aqui tratada:

MASSABINI, V. G. O construtivismo do professor: de Piaget às ideias e práticas de professores de Ciências. Araraquara, 2005. Tese (Doutorado em Educação Escolar). Unesp.

QUIM, O. Teoria e prática na percepção de professoras: concepções construtivistas que fundamentam o processo de alfabetização em escolas de Alto Araguaia MT. Araraquara, 2004. Dissertação (Mestrado em Educação Escolar). Unesp.

RAMOZZI-CHIAROTTINO, Z. Piaget: modelo e estrutura. Rio de Janeiro: J. Olympio, 1972.

SILVA, R.C. Saberes construtivistas de professores do Ensino Fundamental: alguns equívocos e seus caminhos. Araraquara, 2005. Tese (doutorado em Educação Escolar). Unesp.

TORRES, L. de C. Do discurso pedagógico ao discurso dos professores: resistência ao Construtivismo e profissionalização docente. Araraquara, 2004. Dissertação (Mestrado em Educação Escolar). Unesp. 